\title{
9
}

\section{Promoting Labour Standards Through Trade: Normative Power or Regulatory State Europe?}

\author{
Jan Orbie*
}

\section{Introduction}

Since the beginning of the millennium, the European Union (EU) has committed itself to promoting the social dimension of globalization. European policy-makers argue that the 'European social model' should be promoted and that basic labour standards should be advanced in the world through a broad range of external activities (Orbie and Tortell 2008). This chapter addresses the EU's contribution to a social globalization through its most powerful external instrument, namely its trade relations with developing countries. I first indicate why the focus on core labour standards and common commercial policies provides an interesting case study for analysing the Union's normative power. The subsequent section elaborates on the social dimension of EU unilateral and bilateral trade policies from 1995 onwards. Then, the implications of this empirical case are considered from a Normative Power Europe (NPE) approach, arguing that the Union's principles, and to some extent also its activities, do indeed increasingly correspond with what would be expected from a normative power, but that its normative impact remains unclear. In conclusion, I problematize the link between the EU's institutional set-up as a 'regulatory state' and the normative content of its trade policies, suggesting that NPE accounts should also consider the ideological dimension of Europe's global role.

\section{Normative power through trade: exporting core labour standards}

The normative power of the discussion introduced in Manners' seminal article (see Manners 2002) cannot be underestimated. Reflecting a broader trend towards examining the less tangible, ideational and ethical aspects of European foreign policies (for example, Manners and Whitman 2000: 4-6), the social constructivist turn in EU studies (for example, Jørgensen 1997), as 


\section{PROOF}

Jan Orbie 161

well as the emphasis on ethical foreign policies by European policy-makers (for example, Chandler 2003; Hill 2003), the NPE idea has acquired a distinctive place in the debate on Europe's global role. The burgeoning literature on the EU as a normative power (for example, Sjursen 2006b; Aggestam 2008; Laïdi 2008; ), including critiques from various corners of the academic world (for example, Diez 2005; Hyde-Price 2006; Storey 2006), have given fresh oxygen to the debate on Europe's foreign policies. The NPE concept has enabled the EU studies community to escape the focus on specific institutions, policy domains and case studies, by engaging in a critical account of 'what the EU is and should be doing in world politics' (Manners 2006e: 179). It has shifted attention to cross-cutting objectives pursued by the EU such as democracy and human rights (Szymanski and Smith 2005; Brantner and Gowan 2008), peace (Björkdahl, this volume), sustainable development (Lightfoot and Burchell 2005), conflict prevention (Manners 2006c) and children's rights (Manners 2008a), while also sparking a meta-theoretical debate on the nature of the EU and its power in the world (Diez 2005; Part I of this book). The NPE idea forces us to consider questions that, while most difficult to answer, are very much worth raising.

Whether the EU's normative power in the world has increased in parallel with the literature on it is, however, less clear. This chapter aims to contribute to this debate by looking at the promotion of social solidarity through European trade policies. More specifically, the integration of core labour standards in the Generalized System of Preferences (GSP) and bilateral trade arrangements between the EU and developing countries are examined. But first, I explain why this is an interesting case study for the NPE hypothesis, indicate how a NPE can be expected to deal with the social-trade nexus and which factors may complicate Europe's normative power role.

\section{The promotion of core labour standards}

One difficulty in analysing the NPE hypothesis has been the absence of clear criteria for assessing Europe as a normative power. In a comprehensive review, Sjursen (2006b: 173) highlights the need for explicit standards to evaluate Europe's normative objectives. The EU's normative basis as identified by Manners (2002: 242-3) was relatively concise and abstract, consisting of five 'core norms' (peace, liberty, democracy, the rule of law, and human rights and fundamental freedoms) and four 'minor norms' (social solidarity, anti-discrimination, sustainable development and good governance). ${ }^{1}$ Despite the EU's broad definition of the social dimension of globalization involving external policy objectives such as decent work, sustainable development, democracy and accountability, and gender equality - European initiatives in this area have mainly focused on the promotion of core labour standards (CLS) (Orbie and Tortell 2008). This chapter focuses on these CLS, which encompass four principles: (a) freedom of association and the effective recognition of the right to collective bargaining; (b) the elimination of 
all forms of forced or compulsory labour; (c) the effective abolition of child labour; and (d) the elimination of discrimination in respect of employment and occupation. They correspond with the EU's minor norms of social solidarity and non-discrimination and, importantly, also with the core norm of human rights (see Manners 2008d: 28-30).

These four principles constitute the 1998 Declaration on Fundamental Rights and Principles at Work, established within the International Labour Organization (ILO). There is a broad international consensus among developing and developed countries, as well as employers and workers, on the universality of these principles. Each principle is recognized as a human right in the Universal Declaration of Human Rights, the International Covenant on Civil and Political Rights, that on Economic, Social and Cultural Rights, and many other international legal standards. The principles are also referred to in numerous international initiatives such as the United Nations (UN) Global Compact and the revised ILO and Organization of Economic Cooperation and Development (OECD) guidelines for multinational enterprises, as well as in private sector codes of conduct. In short, the ILO Declaration places the CLS at the centre of international human rights law (Alston 2005: 3).

In addition, the CLS have been given a solid formulation in specific ILO conventions. Each of them is reflected in two 'fundamental ILO conventions': Conventions Nos 87 and 98 (the right to organize and collective bargaining), Nos 29 and 105 (the prohibition of forced labour), Nos 138 and 182 (the minimum age of employment of children and the abolition of the worst forms of labour) and Nos 100 and 111 (non-discrimination in employment and occupation). An innovative feature of the 1998 Declaration is that the obligation of member states to promote and realize these principles stems from their mere membership of the ILO, regardless of whether they have ratified the corresponding conventions. The Declaration also established new follow-up mechanisms, including an annual review of the non-ratified fundamental conventions.

Thus, the promotion of these four CLS and the concomitant ILO conventions clearly corresponds with what would be expected from the EU as a normative power. The principles are in line with the normative basis of the EU and they can be linked to cosmopolitan international law treaties of the ILO. In this chapter, I attempt to gauge, from a NPE perspective, whether and to what extent the EU contributes to the ratification and implementation of these fundamental ILO conventions.

Inversely, the normative power quality of the EU's international policies promoting labour standards would be jeopardized if the relevant ILO conventions were discarded, or if they were used in a selective and arbitrary way, for example, for protectionist, commercial or geopolitical purposes. European policy-makers' discourse on the social dimension of globalization has emphasized the importance of the CLS as defined by the ILO, but they 
have also pointed to the need to 'export the European social model' to the world. The idea that a particular European model and specific EU labour standards should be promoted abroad, without international treaty reference points but exclusively rooted in the domestic politics of the EU and its member states, would hinder the Union's normative power. In such a scenario, the EU's demands would not be considered legitimate or feasible by developing countries. ${ }^{2}$ This point is illustrated in Kissack's (2009) analysis of the EU's negotiations on international labour conventions in the ILO. Analysing the negotiation and ratification of the 50 ILO conventions adopted since 1973, Kissack comes to the paradoxical conclusion that the more active the EU is during the drafting of an ILO convention, the lower the number of ratifications it receives from ILO members. When the EU attempts to shape future norms through influencing the content of ILO standards, those standards remain largely unsupported by other states. These conclusions qualify the often assumed natural synergy and harmony of interests between the EU's social model and the ILO's objective of improved global working standards. Uploading the EU model into the ILO creates 'a lose-lose scenario, where the ILO gets a widely ignored maximal standard, and the EU gets a negligible extension of its own standards internationally' (Kissack 2009: 105).

A second caveat concerns the inconsistency between internal and external EU policies. The EU's competence to negotiate, ratify and enforce ILO (core) labour standards inside the EU is limited. ${ }^{3}$ In view of these difficulties faced by the Union in stimulating and enforcing the fundamental ILO conventions internally and its inability to guarantee member states' compliance, attempts by the European Commission to do so in developing countries could be seen as hypocritical. One such case was the EU's introduction of GSP trade conditionality based on developing countries' compliance with ILO conventions in 1998, even though not all the EU member states had ratified the relevant conventions at that time (Novitz 2002: 261; Clapham and Martignoni 2006: 235). In fact, it took until 2007 before all EU members ratified the eight fundamental ILO conventions. In general, EU member states remain reluctant to cede social competences, an attitude which can be explained by the considerable variation in social preferences among European countries (see Manners 2008d: 36). The diverging European views on the international promotion of CLS have clearly surfaced in the discussions on the social-trade nexus, with ideological disagreements between free traders and more interventionist governments. For example, during the crucial discussions on a social clause at the Singapore Summit of the World Trade Organization (WTO), the Council Presidency was unable to come up with a common European position (Orbie et al. 2008: 153-6; see below).

A third caveat concerns the possibility of a hidden consistency between EU internal and external policies, which can be perceived by considering Europe's essential market-led orientation. The pursuit of a neoliberal agenda, where social solidarity is subordinated to economic integration, does not 
seem consistent with a NPE. However, there is some room for confusion about the ideological tendencies of a normative power in socio-economic issues. While it seems obvious that a NPE would not pursue neoliberal norms and unbridled market integration, it is unclear how it would deal with the tension between market-making policies (economic freedom) and interventionist or redistributive policies (aiming at social solidarity, equality and sustainable development). When analysing the Union's normative power in socio-economic cases, one inevitably touches on difficult ideological discussions. Manners (2006e: 179) has indicated that different normative objectives can lead to contradictory results, but he has not elaborated on the ideological tensions inherent to a NPE's policies. Nor have NPE accounts addressed the question of whether the Union's institutional structure - its 'hybrid polity' (Manners 2002: 240) - favours economic liberalization over social regulation. 'Social freedom' including trade liberalization forms one of the Union's core norms, but a clash between the norms of market integration and social solidarity seems inevitable. For example, in an examination of the EU's internal and international approaches to collective labour relations and gender equality, Novitz (2008) argues that the EU is exporting a 'market model' rather than a 'social model', reflecting the particular role that labour standards and gender norms can play foundationally within a European labour market structure. Simply summarized, market objectives usually take priority over social aims. When examining the EU's global social policies through trade instruments, the possible prioritizing of market goals stemming from the EU's political system will be kept in mind, and reconsidered in the conclusions of this chapter.

Thus, the EU's normative principles can be evaluated against the role played by the fundamental ILO conventions in its external policies. However, to the extent that the EU makes reference to particular features of the so-called 'European social model' and/or its competence to act in external social affairs remains limited and/or the social preferences of its member states diverge and/or market considerations take priority above social solidarity, the Union's normative power is harmed. If the EU manages to overcome these hurdles in the international promotion of CLS, it will be able to 'live by virtuous example' (see Manners 2008b: 56).

\section{The leverage of trade conditionality}

Although the EU has developed a broad approach to the promotion of the social dimension of globalization, it has to a large extent relied on the leverage of its trade instruments. NPE accounts have scarcely focused on the EU's external trade policies. More generally, academic work on the EU's international role seems to presume that the objectives pursued in this area are restricted to 'selfish' or 'self-interested' economic goals. It is indicative that Youngs' (2004: 416-9) comprehensive review of the NPE literature has no single study explicitly focusing on EU trade policy. To some extent Van 
den Hoven's (2006) analysis of the EU's 'regulatory capitalism' and multilateral trade negotiations, Szymanski and Smith's (2005) account of the Commission's 'rhetorical action' on democracy and human rights in the EU-Mexico agreement, and Storey's (2006) perspective on Economic Partnership Agreements are exceptions. Conversely, EU trade literature has been dominated by political economy and rational choice institutionalist perspectives that either neglect the normative dimension of EU commercial policies or reduce this issue to the traditional protectionist/free trade dichotomy whereby social considerations are seen as protectionist sentiments spurred on by trade unions, vulnerable industries and short-sighted policy-makers. To some extent the analyses by Meunier and Nicolaïdis (2005) of the EU's 'power through trade', Elgström's (2000) research into norms in the Lomé reform and Young's (2007) considerations of the EU's 'social trade policies' are exceptions. Some anecdotal evidence of the high walls between these two academic strands surfaced at one workshop in 2004 on the EU's international role during which participants started to identify themselves as either 'norm people' or 'trade people'. 4

Obviously, there are good reasons for bridging the two perspectives and considering European trade relations from a normative perspective (see Orbie 2008: 51-5). For one thing, the constitutive principles which characterize the EU as a normative power are also, and increasingly, present in its trade policies. Since the second half of the 1990s, EU trade policy discourse has devoted much attention to the promotion of the development of the South, human rights and sustainable development (Van den Hoven 2006: 188). Before this time, Europe's trade objectives were basically translated into economic interests. Trade policy was the 'core business' in both senses of the word - of EU external policy. Then, instigated by Directorate-General (DG) Trade and Northern member states and influenced by the increasing politicization of trade relations, the Commission deliberately put 'sustainable development' and 'social solidarity' at the heart of EU trade policy discourse. This pursuit of normative objectives is at the centre of the overarching trade objective of 'harnessing globalization' - the favourite motto of former Trade Commissioner Pascal Lamy.

It is no longer only economic interests that are in question, but also values, the concept of society, of what is desirable and of what is risky. Health, environment, the quality of life, culture are henceforth stakes that must be reconciled with open and competitive markets. Regarding development, human rights, social and environmental standards, the European Union brings with it values that have the aim of becoming universal. (Lamy, cited in Agence Europe 1999)

The Union's normative principles have also been institutionalized in its legal framework. Whereas the trade articles in the Maastricht Treaty did 
not explicitly mention normative objectives besides 'the harmonious development of world trade, the progressive abolition of restrictions on international trade and the lowering of customs barriers' (Article 131 Treaty on European Communities (TEC)), the consistency requirement (Article 3 Treaty on European Union (TEU)) implied that the EU's foreign policy principles of 'democracy and the rule of law, and respect for human rights and fundamental freedoms' (Article 11 TEU) also apply to trade policies. The Lisbon Reform Treaty strengthens the consistency requirement in two ways. On the one hand, it adds to the Title on 'trade' the stipulation that Europe's common commercial policy 'shall be conducted in the context of the principles and objectives of the Union's external action' (Article 207(1)). On the other hand, the Treaty's Article on the EU objectives in the wider world explicitly refers to trade; alongside 'free trade', Article 3(5) speaks of 'fair trade'. Although the exact meaning of this latter phrase is unclear, it cannot be seen as a veiled reference to protectionism, but rather fits in with the other normative foreign policy objectives listed in this Article such as peace, sustainable development, solidarity, eradication of poverty, human rights and the rights of the child (Eeckhout 2004: 53).

These evolutions have also manifested themselves in the EU's trade activities. Since 1995, all EU trade and cooperation agreements with third countries contain an 'essential elements clause' on democratic principles and human rights; the EU's GSP trade preferences include labour conditionality, and its bilateral trade agreements contain provisions on social cooperation; since 1999, DG Trade uses trade sustainability impact assessments (Trade SIAs) to analyse the economic, environmental and social impact of trade agreements, both in Europe and among its trading partners.

A second reason for studying trade policy from a NPE approach is that this is the oldest, most integrated and most powerful EU external policy domain. The conditioning of access to the vast and prosperous European market provides the EU with a considerable leverage in the world (Smith and Woolcock 1999). Because the EU's trade activities occupy central and influential position in its foreign policy machinery, analysing their normative dimension allows us to go beyond what the EU says and to analyse what the EU does. In other words, trade policies are an interesting area in which to consider the translation of European principles into external policy activities. Because trade negotiations by definition involve trade-offs between various policy objectives, they make it possible to assess the relative importance attached not only to specific aims such as labour standards but also to agricultural interests, environmental issues, intellectual property rights, investment rules, industrial tariffs and other factors. Europe's commitment to social norms can also be 'measured' by analysing the extent to which the EU is willing to open its markets to products from developing countries where CLS are observed. 
Thus, focusing on trade policy may lead to a 'best case' approach for analysing Europe's normative power, since this is an area where normative objectives tend to compete with offensive and defensive economic interests. For example, Lightfoot and Burchell's (2005: 83, 90) research on the 'sustainable development' norm of the EU found that when it comes to trade, the Union finds it difficult to behave as a normative power and gives priority to 'free market liberalism'. Given the commercial interests at stake and the broad trade agenda of the EU (Young 2007), social norms will easily come into conflict with other external policy objectives.

However, simply incorporating a social clause into trade relations would not necessarily confirm the NPE hypothesis. International discussions on trade-labour linkages have always raised fears of protectionist interest behind a normative smokescreen. Free traders and developing countries resist the idea of a social clause, arguing that the pursuit of lofty ideals such as the elimination of child labour would be used to impede developing countries' market access to Europe, and thus undo their comparative advantage in low-wage production. This explains why the discussions on a labour-trade linkage in the WTO during the 1990s were not successful (see below). Many developing countries have ratified the fundamental ILO conventions and agree with their contents, but they prefer the ILO's soft governance approach to the binding trade regime of the WTO. Therefore, a major challenge for the achievement of social objectives through trade is overcoming the resistance of the developing world by making clear that protectionist motives are not in play. This may be particularly difficult for the EU, given its image as a protectionist trade actor towards the South (Elgström 2007: 959).

From a NPE perspective, social trade arrangements would be based on dialogue, persuasion and positive conditionality, and provide substantial incentives in terms of market access and development assistance. Given the legitimate fears for protectionist misuse, sanctions against developing countries would only be invoked after extensive dialogue and deliberation, and when there is an international consensus about the persistent violation of fundamental ILO conventions. When applying positive or negative social conditionality, it seems necessary to involve civil society organizations and third country governments into the decision-making process and to take the ILO's follow-up procedures on the core labour conventions into account. Overall, such an approach seems to follow the ethics of 'being reasonable' and 'doing least harm', as Manners (2008b: 58-9) calls them.

In addition, if the EU meets these conditions, a normative impact outside Europe may be expected. An expected empirical outcome would be increased compliance with the ILO fundamental conventions in the domestic setting of Europe's trading partners. Although compliance with CLS depends on various factors beyond the EU's control, a NPE through trade would need to have some measurable influence on the ratification and implementation of the relevant ILO conventions by using its trade leverage. Ultimately, and 
more importantly, a NPE should be able to shape conceptions of 'normal' in international relations (Manners 2002: 239, 2008d). Applied to the topic of this chapter, this means that the EU's activities would re-legitimize the idea of a linkage between trade and social norms. If the Union's trade policies manage to promote CLS based on ILO treaties, in a coherent and consistent way, with a focus on dialogue and incentives, and without resorting to protectionist abuses, the artificial division between social and trade regimes might be transcended. When the integration of social and trade issues is again considered a 'normal' thing in international politics - as it used to be in the post-war consensus of 'embedded liberalism's - the impasse over the social-trade nexus in the WTO can be broken (see also Manners 2009b: 798800). This would make an end to accusations of hidden protectionism, and might lead to more fruitful discussions on the interaction between trade and social policies, paving the way for a more sustainable trading regime.

\section{Labour standards in unilateral and bilateral trade policies}

Bearing this NPE perspective in mind, this section elaborates on the social dimension of the EU's unilateral and bilateral trade policies. The EU's role in the debate at the WTO is not addressed because, as explained in this and the following paragraph, labour standards are excluded from the multilateral trade discussions. By the end of the Uruguay Round, the United States (US), most European governments as well as the Commission and the European Parliament argued that internationally recognized labour standards should be included in the new multilateral trade regime. A last-minute compromise meant that the issue could be put on the WTO agenda at a later stage. During the subsequent years, the debate on a social clause became increasingly politicized, culminating in the WTO Singapore Conference in 1996. The Singapore Declaration de facto relegates the issue to the sidelines, referring to the ILO as the competent organization to deal with international labour standards, thereby consolidating the idea that social issues are not to be dealt with in the multilateral trade regime (see Wilkinson 2001: 402, 411). EU and US attempts to put this on the agenda at the Millennium Round failed with the collapse of the 1999 WTO Summit in Seattle, partly because of the growing assertiveness among those developing countries which strongly rejected US President Clinton's suggestion of introducing a sanctioning social clause in the WTO. When a new trade round was finally launched in Doha (2001), the agenda simply referred to the Singapore text. As a consequence, labour standards are not on the negotiating table.

Although the EU has favoured the inclusion of labour standards in the WTO talks since the end of the 1990s, this idea has not been enthusiastically supported by all the member states, and other trade-related issues seem to take priority (Orbie et al. 2008). In addition, the EU also encountered strong resistance from developing countries in this matter. For both these reasons, 
it remains difficult to analyse the Union's commitment to a social clause in the WTO. It is easier to distil the 'EU factor' in unilateral and bilateral trade policies, where the European influence is considerably stronger. In addition, these trade arrangements offer a possibility for the EU to evade the stalemate in the WTO. As argued by Grynberg and Qalo (2006: 651), they could be seen as 'a sort of Trojan horse, a precedent setting means of introducing new issues into the WTO negotiating process'.

\section{Social conditionality in the European GSP system}

The GSP ${ }^{6}$ was established under the Enabling Clause of the General Agreement on Tariffs and Trade (GATT) in the 1970s, as an exception to the Most Favoured Nations (MFN) principle. It allows industrial countries to grant more favourable and non-reciprocal tariff preferences to developing country imports. GSP regulations are approved by qualified majority vote in the Council based on a European Commission proposal; the European Parliament is not formally involved. Third countries do not participate in the discussions on a new GSP, but the regulation must be in line with WTO rules.

The EU's first social conditionality system, introduced in 1995, was limited to trade sanctions. The legal basis for temporary withdrawal of GSP preferences was 'practice of any form of forced labour' or 'export of goods made by prison labour'. The European Commission had wide powers of discretion in the suspension procedure, although the final responsibility lay with the Council (Brandtner and Rosas 1999: 715). ILO findings were not mentioned in the sanctioning process. This new system soon resulted in two complaints by the international trade union movement against alleged abuses of labour rights. In the case of Burma (Myanmar), the Commission decided to investigate practices of forced labour and hearings were held with non-governmental organizations (NGOs), journalists, medical personell, specialists in international law, Burmese individuals and other parties. Whereas, as a result of this procedure, Burma was sanctioned in 1997, a complaint against child labour in Pakistan in the same year never even got as far as an investigation, allegedly because the social GSP clause did not yet allow for a suspension on the basis of child labour. ${ }^{7}$ In 2001 the reasons for temporary withdrawal were extended to include 'serious and systematic violation' of any standards referred to in the 1998 ILO Declaration. In addition, the 'available assessments, comments, decisions, recommendations and conclusions' of the ILO have since served as the 'point of departure' in any investigation as to whether temporary withdrawal is justified. Under this system Belarus was sanctioned because of violation of ILO Conventions Nos 87 and 98 in July 2007.

Since 1998, developing countries have been entitled to apply for the social incentive regime. Again, the Commission plays an important role in decisions on GSP preferences, while no reference is made to the ILO's findings. 
This sparked criticism that the Commission lacked the means and expertise to make such evaluations and to carry out fact-finding missions and that, once an incentive tariff had been granted, the monitoring of labour rights depended largely on Europe's confidence in, and cooperation with, the beneficiary country's authorities (Dispersyn 2001: 103). Substantively, the GSP regulation of 1998 referred only to a limited number of the core ILO conventions: beneficiaries of the additional trade preferences had to comply with Conventions Nos 87 and 98 concerning freedom of association, and Convention No. 138 concerning child labour, but it did not extend to any of the conventions concerning forced labour or discrimination. This provoked remarks that the EU was adopting 'double standards' compared with the punitive regime for the violation of forced labour. Tsogas (2000: 363-4), for example, castigated the dual character of the EU system for going against the universality of the ILO fundamental rights: 'It seems that, according to this peculiar EU "carrot and stick" approach, exploiting children and organizing death squads against trade unionists are less serious breaches of human rights than running forced labour camps!'

Consistency with the ILO Declaration was brought a step closer in the 2002 reform. The new GSP stated that the EU must take the findings of the ILO into account when examining applications for GSP incentives. Moreover, the legal basis of the incentive clause was extended to all eight of the core conventions. However, the GSP regulations only talked about the incorporation of the 'substance of' the relevant ILO conventions in national legislation, and about their effective implementation. It was not until 2005 that the ratification of these conventions was required. At this time, a more fundamental reform of the EU's GSP conditionality system was implemented. One reason for the overhaul of the system was its limited success: only Moldova (2000) and Sri Lanka (2004) had successfully applied for social incentives. This disappointing result was partly explicable by the cumbersome administrative procedures, the relatively limited preferential benefits compared with the standard GSP, the availability of alternative trade systems for exporting to the EU market and ideological resistance to the idea of a social clause. But the immediate impetus for the reform was a case brought before the Dispute Settlement Body of the WTO against the EU's GSP system.

Shortly after 9/11 the EU added Pakistan to the beneficiaries of the GSP drugs system, which provided additional trade preferences to Latin American countries ${ }^{8}$ fighting drug trafficking and production. This addition provoked a fierce reaction from the Indian government, which argued that the EU's decision was motivated by foreign policy and geopolitical motivations and not justified under the GATT Enabling Clause. The WTO Appellate Body ruled that developed countries are entitled to grant additional preferences if these are based on objective and transparent criteria (see Bartels 2005). In other words, the introduction of labour standards 
in GSP is in itself not illegal, nor does it run counter to the consensus at the WTO, but the problem in this case was that the EU had granted incentives in a discriminatory way (Grynberg and Qalo 2006: 648). As a consequence, Europe's social GSP had to be reformed in line with this ruling. The new GSP regulation abandoned the separate social clause and incorporated labour provisions into a broader 'sustainable development and good governance' regime. All vulnerable countries were eligible for these 'GSPplus' incentives, provided that they 'ratify and effectively implement' 16 human rights conventions, including the fundamental ILO conventions ${ }^{9}$ and at least seven (out of 11) conventions on environment and governance, ${ }^{10}$ by the end of 2008 . The regulation also makes clear that the Commission's examination of countries requesting special incentives shall take into account the findings of the ILO and that the Commission will monitor the compliance of beneficiary countries making use of the ILO assessments.

Thus, the relevance of the ILO has increased considerably through successive reforms of Europe's GSP conditionality system, both in relation to decision-making procedure (taking ILO findings into account) and substantive content (ILO conventions). In the first GSP regulation the ILO was barely mentioned (1995), then the contents of some (but not all) conventions was mentioned but without a ratification requirement (1998 and 2002), and finally the ratification and effective implementation of the eight fundamental ILO conventions became a necessary condition for GSP-plus applicants (2005). The provisions on GSP-plus in the new GSP regulation (2009-11) remain unchanged.

Fifteen countries were included in the GSP-plus scheme from 1 January 2006. The GSP-plus has been successful in ensuring the full ratification of the eight fundamental labour standards among the beneficiary countries. Bolivia, Colombia, Venezuela, Mongolia and El Salvador each ratified one or more of the core labour conventions during the period 2005-06, seemingly because, without those ratifications, they would have lost their beneficiary status. However, critics have argued that ratification is cheap. Members of the European Parliament ${ }^{11}$ and civil society organizations ${ }^{12}$ point out that some GSP-plus beneficiaries have received sharp criticism from the ILO bodies, raising the question of whether the new system is more than simply a 'tick the box' exercise in ratifying international conventions. The impression that implementation of the relevant ILO conventions has not been considered is reinforced when looking at the list of GSP-plus beneficiaries, which reveals that all former drugs beneficiaries from the Andean Community and the Central American Common Market successfully switched over to GSPplus incentives. ${ }^{13}$ It seems that the GSP reform merely amounts to a recycling of the former drugs system, whereby ratification of the relevant conventions constitutes an easy way to continue preferences already granted to Europe's Latin American partners. 
Does this allegation make sense - to what extent is the EU's practice of social conditionality consistent with ILO findings? A study of reports on these Latin American countries by authoritative ILO committees (see Orbie and Tortell 2009) reveals considerable divergence with regard to implementation of the CLS. Some GSP-plus beneficiaries have received serious condemnation (for example, Colombia, Guatemala, Venezuela) whereas others have been evaluated more positively (for example, Bolivia, Ecuador, Honduras). ${ }^{14}$ At the time of writing, the EU has not withdrawn GSP-plus preferences on the grounds of insufficient implementation of ILO core conventions. ${ }^{15}$ In contrast, the EU's application of GSP sanctions has been more consistent with ILO assessments. Since the system was created in 1995, only Burma and Belarus have been sanctioned under GSP conditionality; and these are the only two countries that have faced an ILO Commission of Inquiry in a period of 15 years. The Union has clearly been reluctant to impose trade sanctions, these having been limited to two cases involving condemnation by the international community in general.

Another restraint on the impact of social incentives is that many developing countries are de jure or de facto not eligible for GSP-plus preferences. For example, the least-developed countries already enjoy free access to the European market under 'Everything but Arms'. By introducing this initiative in 2001, the EU allowed the poorest countries to bypass the GSP incentive system. More prosperous developing countries such as Thailand, Pakistan, India or Indonesia also remain out of the scope of positive social conditionality, because only 'vulnerable' countries are eligible for GSP-plus. The definition of 'vulnerable' has been criticized for being based on a developing country's share in imports into the EU, and not on development criteria (Bartels 2005). Moreover, several developing countries such as Mexico, South Africa, Chile and the African, Caribbean and Pacific (ACP) countries have concluded, or are in the process of negotiating, free trade agreements with the EU, so that their exports to the European market no longer fall under the GSP. Peru and Colombia will probably sign a trade agreement with the EU in March 2011, while the other members of the Andean Community (Ecuador and Bolivia) and the Central American region (Costa Rica, El Salvador, Guatemala, Honduras, Nicaragua and Panama as observer) are negotiating an association agreement. When all these countries conclude a bilateral trade arrangement with the EU, the relevance of the GSP social conditionality system will be significantly downgraded. This brings us to the question of the next section, namely the extent to which labour standards are integrated into bilateral trade arrangements.

\section{Labour standards in Europe's bilateral trade agreements}

Although multilateral trade negotiations have been a priority for the EU since the creation of the WTO, the Union has also continued to negotiate bilateral trade agreements with developing countries (Lamy 2002), and this 
bilateral track has received a new impetus with the 'Global Europe' strategy (European Commission 2006c). One might expect that bilateral agreements would be more normatively inspired than the GSP because the European Parliament is more involved and because the Commission plays a central role as the EU negotiator (see Szymanski and Smith 2005: 186-7). However, these agreements generally involve countries where important commercial interests are at stake and such countries are typically reluctant to accept labour provisions.

The EU-Mexico agreement concluded in 1997 has only one Article on 'cooperation on social affairs and poverty' (Article 44). It states that both parties will conduct a dialogue on social issues of interest to both parties, but does not refer to the ILO. Social standards in the agreement with Chile (2002, Articles 43-44) are equally limited to dialogue and cooperation, but the wording is more extensive and both parties commit themselves to promoting the fundamental ILO conventions. The Trade, Development and Cooperation Agreement signed with South Africa in 1999 also mentions the ILO CLS, not only in the provisions on cooperation (Article 86) but also in the preamble.

The Cotonou Agreement (2000) seems more ambitious and might lead to a binding social conditionality. The preamble states that the EU and the ACP are 'anxious to respect basic labour rights, taking account of the principles laid down in the relevant conventions of the International Labour Organization'. Article 50 was seen at the time as a model in promoting CLS through bilateral trade, to be extended to other agreements (European Commission 2001: 18). Its title is 'Trade and Labour Standards', though in effect it only contains both parties' intention to cooperate on social affairs. This Article also confirms the parties' commitment to ILO CLS and states that 'labour standards should not be used for protectionist trade purposes', echoing the Singapore Declaration. More importantly, in Article 9 the 'fundamental social rights' are explicitly considered as part of the 'essential elements' of the agreement, standing on an equal footing with the principles of human rights, democracy and the rule of law. This implies not only that ILO CLS can be the subject of a structured political dialogue between the EU and an ACP country, but also that substantial violations of these principles could lead to consultations and, eventually, 'appropriate measures' in line with Article 96 procedures.

At the time of writing, the social provisions of Cotonou have not been implemented. An internal European Commission evaluation in 2007 concluded that 'we could have done more'. ${ }^{16}$ Research by Kerremans and Gistelinck (2009) shows that the promotion of CLS through Article 50 has been overwhelmed by other foreign policy and trade priorities such as weapons of mass destruction, the International Criminal Court, the fight against terrorism, Economic Partnership Agreements, climate change and the political situation of individual ACP countries. Similarly, the possibility 
of including CLS in the political conditionality system has not been tested in practice. 'Article 96 consultations' have mainly dealt with violations of democratic principles, good governance and the rule of law.

However, in 2007 a more far-reaching agreement was signed with the Caribbean ACP countries. The EU-CARIFORUM Economic Partnership Agreement includes a commitment to upholding the existing levels of social protection, which minimally reflect the CLS of the ILO. It refers to labour standards in the context of foreign direct investment, with respect to trade overall, and with respect to the dispute settlement procedure, and stresses that labour standards cannot be used for protectionist purposes. For example, the agreement stipulates that foreign direct investment should not be encouraged if it leads to lowered domestic environmental, labour or occupational health and safety standards. The dispute settlement procedure contains specific references to labour standards and non-compliance with the panel's findings can lead to 'appropriate measures'. However, when the dispute concerns labour standards, the agreement does not allow the suspension of trade concessions or financial compensations. Although this is a step forward compared with other EU agreements, it seems that 'beyond blaming and shaming as a consequence of a negative panel outcome, there is not much else available to pressurize the parties to the agreement to comply with its labour and environmental provisions' (Kerremans and Gistelinck 2009: 310).

Meanwhile, the EU is negotiating association agreements with the Central American region and with Bolivia and Ecuador (see above), and free trade agreements with South Korea, India and some members of the Association of Southeast Asian Nations (ASEAN) (negotiations with Vietnam and Singapore were launched in 2010). The European Commission underlines that this is the first time that EU trade negotiation mandates so extensively cover social and environmental concerns in a separate sustainable development chapter, and that these issues constitute a key element of the Commission's new trade agenda. DG Trade has announced that the new generation of European Free Trade Agreements (FTAs) should constitute a step change in how the EU integrates its sustainable development agenda with trade policy (Bossuyt 2009: 703). However, although the Commission managed to rally the EU member states behind the inclusion of social issues in the pre-negotiation phase, it is still unclear if this unanimity will hold up when difficult trade-offs have to be made during the final stages of the negotiations with Asian and Latin American partners. It should be noted that CLS provisions are not a priority for EU member states, although some governments (for example, the UK, France and Denmark) attach more importance to it than others (for example, Spain, Poland and Germany) (Bossuyt 2009: 713-18).

The labour standard provisions in the free trade agreements with South Korea and Peru/Colombia (not yet ratified at the time of writing) are at a somewhat similar level of ambition as the EU-CARIFORUM agreement. 
The case of Colombia is particularly interesting because the EU has been criticized for not invoking GSP sanctions as a response to violations of trade unions rights (see above). Although the agreement includes a democracy clause, which is exceptional for an FTA (as opposed to association agreements), there are no enforcement mechanisms under the sustainable development chapter. Instead, a 'Council on Trade and Sustainable Development' would be established in order to oversee the implementation of the chapter and engage in a dialogue on social and environmental issues. Compared with the GSP system, there may be more opportunities for dialogue and for a cooperative approach, but the labour standard provisions also seem more difficult to enforce legally.

However, the negotiations with India will be a major test. India has always been among the most hostile opponents of a social clause in the WTO, and it has already rejected the incorporation of an essential elements clause in the agreement. The Commission wants to convince India that CLS are not a protectionist tool, but rather a guarantee of fundamental rights; it emphasizes that none of the social provisions will be binding. It is also encouraging the ratification by India of ILO Conventions Nos 138 and 182 on child labour (Bossuyt 2009: 720).

Although the EU has taken an essentially ad hoc approach tailored to the trading partner at the negotiation table, some general conclusions can be drawn. The core ILO conventions have become increasingly relevant principles in the EU's bilateral agreements. However, labour standard provisions have been formulated in the context of development cooperation and political dialogue, rather than trade measures. There are no enforcement mechanisms, except perhaps through the essential elements clause in Cotonou. In addition, the social provisions have scarcely been implemented in practice. The incorporation of the ILO's CLS into the 'essential elements' of new agreements is an important confirmation of their human rights status, and a potential reason for conditionality including dialogue as well as sanctions. But the EU's conditionality practices based on violations of the essential elements clause shows a preference for the first generation (civil and political rights) over the second generation (social and economic rights) of human rights (see Clapham and Martignoni 2006: 291). One might argue that the prominence of ILO conventions and the non-binding, deliberative and developmental approach fits in with the NPE thesis; but it remains to be seen whether the EU's actions in this area will have any normative impact, and whether they are put on an equal footing with other trade-related objectives.

\section{What the EU says, does, achieves... and is}

In the past decade, the EU has pledged to promote the social dimension of globalization, pursuing a wide range of objectives and using a variety of 
external policy instruments. This chapter has focused on a central aspect of the EU's global social agenda, namely the integration of core labour standards into European trade relations. More specifically, I have analysed the social dimension of the EU's unilateral and bilateral trade arrangements between 1995 and 2008. It has been argued that this case study could shed light not only on what the EU says, but also on what it does and what impact it has from a NPE perspective. In terms of Manners' 'tripartite analytical method' (2008a: 239, 2008b: 47, 2009b), it can be concluded that normative principles have become an important part of EU trade policies, that despite some shortcomings the EU has also started to engage in normative trade activities and that it remains to be seen whether the EU will have any normative impact in this respect. In this concluding section I briefly summarize these conclusions and raise some questions about the link between the EU's institutional architecture and the ideological substance of its normative power.

The importance of cosmopolitan international law treaties in the EU's social trade relations has noticeably increased. While the first GSP regulation did not refer to ILO conventions or procedures, the GSP-plus system now explicitly requires the ratification and effective implementation of the fundamental ILO conventions and aims to take the ILO's findings into account when granting or withdrawing trade incentives. In 2008 the European Commission (2008a) prepared an extensive report on the ratification and implementation of the GSP-plus conventions as evaluated by the international monitoring bodies such as the ILO.

A similar evolution has taken place in the EU's bilateral trade agreements. In contrast with the agreements that were signed halfway through the 1990s, the EU's new bilateral agreements include a commitment by both parties to promote core labour standards, as defined by the ILO. As argued in the first section of this chapter, the universality of these social principles is widely acknowledged. Thus, it seems that the EU has successfully avoided the temptation to promote a particular 'EU model' involving specific social regulations, for example, by seeking a harmonization on wages or safety standards at the workplace. Unlike the free trade agreements negotiated by the US (Grynberg and Qalo 2006: 651), the EU does not require the parties to include in their domestic laws labour standards which go beyond those listed as CLS by the ILO. Neither has it defended the promotion of CLS in terms of 'social dumping': the European Commission's discourse has always stressed that this is a matter of basic labour rights as human rights, rather than economic competitiveness. It should also be noticed that while these rights were initially pursued through trade instruments only, trade strategy has now become part of a wider EU approach to the social dimension of globalization (Orbie and Babarinde 2008: 464-5).

It is more difficult to assess how these normative principles have shaped the Union's normative trade activities. The implementation of social trade 
conditionality by the EU has often been limited and sometimes even dubious. The GSP-plus seems more successful than its predecessor, granting trade incentives to 15 developing countries that have ratified the fundamental ILO conventions and a number of other multilateral treaties. However, many developing countries have been excluded as potential beneficiaries of social incentives through alternative trade arrangements of the EU. For example, the GPS-plus does not apply to the poorest or to more prosperous developing countries. There are also suggestions that the GSP-plus conditionality system boils down to a recycling of the drugs preferences that were ruled illegal by the WTO and that some Latin American beneficiaries have merely ratified but are not implementing the relevant ILO conventions. According to the European Commission (2008a: 6), the international bodies such as the ILO reveal 'various shortcomings in the implementation process but in general demonstrate a satisfactory state of play' (however, see Orbie and Tortell 2009). The difficulties in implementing social trade provisions have become even more obvious in the EU's bilateral agreements. Cooperation and dialogue on social affairs under the Cotonou Agreement have barely taken place, and procedures following violations of the 'essential elements' of the agreement have not dealt with socio-economic human rights. If we look at what the EU does, there is still a disparity between the first and second generation of human rights, whereby basic labour rights seem to be considered under the minor norms of social solidarity and non-discrimination, rather than under the core norm of human rights.

Therefore, it does not come as a surprise that the EU's normative impact has been limited. However, the EU's policies in this area might have set the stage for more substantial results in the future. First, the GSP-plus regulation has influenced the European trading partners' compliance with CLS. An important symbolic achievement has been the ratification of some fundamental ILO conventions in Latin American countries, stimulated by the prospect of GSP-plus beneficiaries. However, this has not yet gone together with an improvement of these countries' implementation records. The reaffirmation of both parties' commitment to the 1998 ILO Declaration and the concomitant core labour conventions in recent bilateral agreements should be welcomed, but these provisions basically confirm commitments already made in the ILO by Europe's trading partners.

A second aspect is that the EU's activities could, in the longer term, increase the legitimacy of the ILO regime. Through its trade arrangements the ILO has been recognized by the EU and its trading partners as the most competent organization to address social issues worldwide. In the second half of the 1990s the ILO, after a period of self-reflection on its new role in the post-Cold War era, managed to reinvent itself by focusing attention on the eight fundamental labour standards. While some critical reflections can be made on the normative motives and consequences of the EU's increased proactiveness in the ILO (Kissack 2009) and on the ideological nature of 
the EU's influence in it (Novitz 2008: 239-41), it cannot be denied that the Union has facilitated the ILO's resurrection.

Given this development, the question now emerges of whether social issues will always remain locked up in the ILO or whether the artificial distinction between the global trade and social regimes can be transcended. This brings us to a third possible normative impact. In the long term, the EU's promotion of labour standards through trade could contribute to more constructive and creative thinking about the linkage between trade and labour. If the EU indeed manages to present the trade-social nexus as something 'normal' in international relations, without provoking fears of hidden protectionism, it will truly assert itself as a normative social power in the world.

The EU's success in this regard will depend on the way in which the EU promotes normative objectives in the context of trade relations. Contrary to those who feared that the Union would behave like a protectionist wolf in social clothing, and to the practices of social conditionality in US trade policies, the EU has hardly ever resorted to trade sanctions. Only in two cases have GSP trade preferences been withdrawn, namely Burma and Belarus. These two countries also received the highest level of condemnation by ILO bodies and were criticized by the international community for severe violations of human rights and democratic principles. GSP sanctions have only been applied after lengthy procedures involving consultation with several actors. Trade Commissioner Pascal Lamy characterized the GSP-plus as 'a distinctive type of foreign policy built around persuasion and incentives rather than threats and demands'. ${ }^{17}$ The EU has clearly lived up to this intention by relying almost exclusively on positive conditionality in the form of increased market access. For example, in the debate on GSP sanctions against Colombia (see above), the Commission emphasizes that it wants to 'use the incentive to the maximum' and claims that the GSPplus has already encouraged progress on labour rights and human rights. ${ }^{18}$ Similarly, social provisions in bilateral agreements have never led to trade sanctions. They essentially focus on development cooperation and political dialogue, as well as declaratory commitments to the ILO CLS. Trade or financial sanctions have been ruled out. Referring to the Singapore Declaration of the WTO, the EU's new bilateral agreements emphasize that labour standards cannot be used for protectionist purposes. In his reflections on the social dimension of EU trade policies, Manners suggests that this non-coercive approach 'illustrates the lengths at which the EU goes to avoid claims of protectionism despite the way this undermines its impact, particularly in terms of conditionality, compliance, and implementation' (Manners 2009b: 797). Further on, he points out that the long-term institutionalization of opportunities for dialogue is perhaps more important than the short-term success or failure of EU promotion of ILO CLS (Manners 2009b: 801). 
Given that its trade-social policies have been constructed around the universal principles of the ILO, and that these have been pursued through positive conditionality, incentives and dialogue, it may be said that to a large extent the EU meets the ethical criteria about 'being reasonable' and 'doing least harm'. This approach might eventually lead to a normative impact on the thinking around a more sustainable multilateral trading system. However, the EU has only recently embarked on normative principles and activities in its trade relations, and their normative impact in the long run remains to be seen. As pointed out by Manners (2008d: 37): 'The diffusion of ideas in a normatively sustainable way works like water on stone, not like napalm in the morning.'

However, some other elements of the EU's approach could hinder its normative impact. The capacity of the EU to 'live by virtuous example' has indeed been qualified by the obstacles identified in the first section of this chapter. To some extent the EU has made progress. Divergences between the EU's internal and external policies have been reduced because all the EU member states have now ratified the fundamental ILO conventions. In contrast with the debates of the 1990s, the EU generally manages to speak with one voice on the trade-social nexus. However, the capacity of the European Community to negotiate, ratify, implement and enforce labour standards internally remains limited, and its member states are still largely in charge of these issues. This could fuel developing countries' critique that Europe is using double standards in 'imposing' social norms. There have also been concerns about the lack of transparency in the EU's unilateral decisions on sanctions or incentives, for example, in the case of Pakistan.

Finally, there are strong indications that other trade-related objectives have taken precedence over the fundamental labour standards of the ILO. Considering normative power through trade is a hard case because tradeoffs with other external policy goals inevitably emerge. Applied to this case, it seems that a more ambitious social agenda has been hindered by the EU's pursuit of free trade. The scope and impact of the positive social conditionality system under the European GSP has been undermined by other EU trade initiatives that are aimed at trade liberalization and do not provide social trade incentives, such as 'Everything but Arms' for the leastdeveloped countries and free trade agreements with several Asian and Latin American countries. Labour standards have been pursued even less vigorously in Europe's bilateral agreements (see Grynberg and Qalo 2006: 625), which are mainly aimed at the reciprocal liberalization of market barriers and behind-the-border issues. The latter involve regulatory disciplines in areas such as investment, competition, government procurement, intellectual property rights and services. They occupy a central place in the 'deep trade' agenda of the EU (Young 2007), while more interventionist and redistributive trade issues tend to be pushed to the periphery (Orbie and Faber 2009: 370). For example, it has been suggested that EU member states 
are less enthusiastic than the European Commission about a far-reaching sustainable development chapter, including ILO CLS, in the new bilateral agreements with Asian countries. The EU's main priorities are in the areas of market access and regulatory disciplines.

EU preferences for free trade and deep trade are inspired not only by economic interests but also by ideological beliefs about the purpose of trade policies (see Orbie 2008: 47-51, 62). Since halfway through the 1990s, a consensus has emerged among EU policy-makers about the positive impact of free trade on economic and social development. In this context, it has also been argued that the European model of regional integration could be exported to the international scene (see Lamy 2002). However, this model is to a large extent based on economic liberalization and regulatory integration. This brings us to the fundamental question about the nature of the EU. The NPE thesis makes a direct linkage between the EU's sui generis architecture and its normative power status, suggesting that the EU is a normative power by virtue of its hybrid polity consisting of supranational and international forms of governance' (Manners 2008b: 45). However, if one conceptualizes the EU as a 'regulatory state' entrusted with correcting the market failures that accompany liberalization (see Majone 1994), or if we look at the 'constitutional asymmetry' between market-enhancing and market interventionist instruments (see Scharpf 2002), a different picture emerges. The Union's institutional machinery may be better equipped to pursue economic integration, while the EU's pursuit of social corrections and redistribution has been more problematical. This inherent bias into the EU's internal policies may also cast a shadow on its global role. The EU is particularly well equipped to promote a deep international trade agenda because of its internal market experience, but this still falls short of a more ambitious approach in line with the idea of 'embedded liberalism'. Paraphrasing Christopher Hill's concept, we may be noticing a widening gap between the EU's capabilities of a regulatory state, and the expectations of a NPE (Orbie 2008).

When elaborating on the way that normative objectives are pursued, normative power accounts barely touch on ideological questions. Nevertheless, it seems that the $\mathrm{EU}$ is institutionally designed to promote market-enhancing policies. A major reason for delegating trade policy to the European Commission is precisely that 'agents' generally favour neoliberal options compared with their 'principals' (see Meunier 2005: 8). As indicated in the first section, the pursuit of free trade and deep integration could also be considered as normative objectives, but it remains unclear how the tension between liberalization and interventionism should be approached from a normative power perspective.

Further research should investigate the relationship between Europe's institutional structure and its normative power qualities, possibly in comparison with US foreign policy. Based on this case study, it can be argued that 
the references to cosmopolitan norms and preferences for a non-binding approach stem from the nature of the EU. The sum of the $27 \mathrm{EU}$ member state trade policies in the absence of the EU would probably be more protectionist and less embedded in international treaties. The EU's hybrid polity makes it more difficult for European policy-makers to engage either in protectionist practices, because trade policies are delegated to the Commission and less influenced by domestic constituencies, or in the imposition of trade sanctions, because this requires unanimity and touches on second pillar policies. But at the same time, the peculiar set-up of the EU also facilitates the creation of a 'neoliberal power Europe', whereby a non-binding and cooperative approach to social issues illustrates a limited commitment to achieving social norms in comparison with a more straightforward and enforceable market-making agenda. A normative trade actor would abstain from protectionist misuse of normative principles, without limiting its activities to the promotion of neoliberal norms. It is still unclear whether this can be achieved by the EU as it currently stands. This case showed that the principles and activities of European trade arrangements have certainly become more normative in the past decade, but the EU (at least as it is presently constituted) may soon be facing the limits of what it can achieve.

\section{Notes}

${ }^{*}$ This research forms part of a Jean Monnet Information and Research Activity on the European Union's global social role (see www.eu-sdg.ugent.be). I am very grateful to my co-organizer Lisa Tortell, to the members of the organizing committee (Tonia Novitz, Ian Manners and Jacqui True), and to Fabienne Bossuyt, Ferdi De Ville, Lotte Drieghe, Myriam Gistelinck and Bart Kerremans for their comments on earlier versions of this chapter.

1. However, see a more extensive elaboration in Manners (2008b: 47-55).

2. See Manners (2006e: 173-4, 176, 2008b: 47) on cosmopolitan versus communitarian approaches.

3. Following a conflict between the Council and the Commission on the ratification of ILO Convention No. 170 on Chemicals at Work, the European Court of Justice (ECJ), Opinion 2/91, argued that the existence of Community legislation on certain labour standards does not necessarily imply an exclusive Community competence to negotiate related conventions within the ILO. When the Community limits itself to setting minimum labour standards, external competence is shared by the Community and member states. As a consequence, there are many facets of social policy in which the EU does not have external competence, especially in respect of pay, the right of association, the right to strike and the right to lock-out (see Novitz 2002; Clapham and Martignoni 2006). However, it appears that coordination of European positions at the ILO has been more successful in recent years (Orbie and Tortell 2008: 13).

4. ECPR Joint Sessions, Workshop 'New Roles for the EU in International Politics?', Uppsala, April 2004.

5. The term 'embedded liberalism' was introduced by John Gerard Ruggie in 1982, in reference to the ideas outlined in Polanyi's The Great Transformation (1944) 
and characterizing the post-war ideological consensus. Briefly summarized, this notion indicates that reliance on the forces of the free market cannot guarantee goals such as development and social progress, and that social values should be embedded in the economic system. Interestingly, the Havana Charter (1948) resulting from the UN Conference on Trade and Employment (emphasis added) foresaw an International Trade Organization (ITO) which included an institutional linkage between trade and labour standards. It also provided for cooperation with the ILO, and made it possible to bring complaints about unfair labour conditions before the ITO's dispute settlement procedures (see Drache 2002). However, after a coalition of 'protectionists' and 'perfectionists' in the US Congress had rejected the ITO, the provisional GATT (General Agreement on Tariffs and Trade) chapter of Havana became the main pillar of the post-war international economic architecture. Labour standards became disconnected from the world trade regime, with the notable exception of an 'ITO remnant' in GATT Article XX(e), which permits governments to ban trade in goods produced by using prison labour. The breakdown of the ITO created a path-dependent process whereby labour standards were seen as incompatible with, and thus separated from, the multilateral trade regime (Wilkinson 2001).

6. This section draws mainly on Orbie and Tortell (2009).

7. Other reasons have been advanced, for example, that the EU was inspired by commercial considerations, that it acted out of development concerns for families in Pakistan, that the EU preferred an incentive-based approach and that the Pakistani authorities were cooperating with the EU (see Brandtner and Rosas 1999; Orbie and Tortell 2009). Apart from substantial considerations, this case shows the ambiguity of the EU's decision-making process: 'the whole procedure has been conducted not only way from public accountability, but in deep secrecy' (Tsogas 2000: 364).

8. This system granted additional market access to Andean Community members (Bolivia, Colombia, Ecuador, Peru and Venezuela) and to members of the Central American Common Market (Costa Rica, Guatemala, Honduras, Nicaragua, El Salvador and Panama).

9. Besides the eight fundamental ILO conventions, this includes: International Covenant on Civil and Political Rights; International Covenant on Economic Social and Cultural Rights; International Convention on the Elimination of All Forms of Racial Discrimination; Convention on the Elimination of All Forms of Discrimination Against Women; Convention Against Torture and other Cruel, Inhuman or Degrading Treatment or Punishment; Convention on the Rights of the Child; Convention on the Prevention and Punishment of the Crime of Genocide; International Convention on the Suppression and Punishment of the Crime of Apartheid.

10. Montreal Protocol on Substances that deplete the Ozone Layer; Basel Convention on the Control of Transboundary Movements of Hazardous Wastes and Their Disposal; Stockholm Convention on persistent Organic Pollutants; Convention on International Trade in Endangered Species; Convention on Biological Diversity; Cartagena Protocol on Biosafety; Kyoto Protocol to the UN Framework Convention on Climate Change; UN Single Convention on Narcotic Drugs (1961); UN Convention on Psychotropic Substances (1971); UN Convention against Illicit Traffic in Narcotic Drugs and Psychotropic Substances (1988); Mexico UN Convention Against Corruption.

11. See, for example, European Parliament (2006). 
12. See, for example, DG Trade (2007).

13. The other GSP-plus beneficiary countries are Georgia, Mongolia, Moldova and Sri Lanka.

14. No noticeable changes in implementation performances between 2005 and 2008 can be noticed.

15. The Commission investigated the implementation of labour rights in El Salvador in 2008-09 and found that temporary withdrawal of the special incentives was not justified, although it continues to monitor the situation. The GSP-plus incentives of Venezuela (2009) and Sri Lanka (2010) have been withdrawn but not because of violation of the labour standard conventions (non-ratification of the Convention against Corruption in the case of Venezuela, and insufficient implementation of the International Covenant on Civil and Political Rights, the Convention Against Torture and other Cruel, Inhuman or Degrading Treatment or Punishment and the Convention on the Rights of the Child in the case of Sri Lanka). An investigation of the implementation of core labour standards in Colombia has not been started.

16. DG Trade official discussion on 'The social dimension of EU trade policies', Ghent, 22 November 2007. Transcripts are available from http://www.eu-sdg.ugent.be (accessed 1 November 2008).

17. Financial Times, 17 October 2004.

18. Peter Thompson, DG Trade, Conference on 'Global Europe and Decent Work', Solidar, 19 November 2009. 


\section{PROOF}

